\title{
FINANCIAL RESOURCES AS A BOUND BETWEEN ECONOMY AND SECURITY
}

\section{Elena FLORIŞTEANU}

\author{
"Nicolae Bălcescu" Land Forces Academy, Sibiu, Romania \\ elena_floristeanu@yahoo.co.uk
}

\begin{abstract}
The current paper is pursuing some of the benefits that could be obtained by each domaineconomy and security - as a result of consolidating one another, as well as the possible dangers and security risks that countries might face, due to low economic performances or security underfunding. The arguments presented seek to increase the level of involvement in solving various challenges of these domains and the understanding that any overlooked disruptive factor or for which no solutions are sought today, may have multiplied future effects. Therefore, joint action is vital since the multiple connections, between economy and security, cause each domain to be foundation of stability and development for the other.
\end{abstract}

Keywords: economy, security, finance resources, poverty, conflict

\section{Introduction}

Security and economy are terms that define independent areas, with different roles for society, whose consolidation may place a state on different levels of power. How does the financial connection between the two areas manifest itself? It is a question that many answers were given to, especially based on the fact that peace, stability and prosperity are considered as a whole. In general, security is analyzed in correlation with development, knowing that the foundation of each state's development lays in its economy which, in the current global context, generates resources not only for the state to which it belongs to, but also for the global economy. At the same time, the connection between security and economy are analyzed in terms of the contribution that the economy has for the provision of specific military equipment and technology (for example the so-called economy of defense or defense industry) of its role in supplying dual-use goods and, often, as a main source in providing the financial resources needed to finance security needs and defense needs, respectively.

\section{Reflecting the Connection between Security and Economy}

The stated approach starts from the meanings of the two terms just as they are found in the Explanatory Dictionary of the Romanian Language [1]: security stands for "the fact of being sheltered from all danger; the sense of confidence and peace that anyone has in the absence of danger", while the economy is depicted as "all human activities carried out in production, distribution and consumption of material goods and services" [2].

Of the short explanation given to the first term (security) I choose to relate to the feeling of peace that the state of security brings about, a feeling that even if not present in the explanation of the second term (economy) is induced at the level of 
the states with a solid economy that allow active people to participate in the economic life. The state of tranquility is felt by those who live in a country which is not torn by conflicts, where peace prevails and the institutions in the field of security operate and perform their roles assigned by society. At the same time, the state of tranquility and confidence is generated by employment, the idea of usefulness to society and self-fulfillment. The connections outlined are simple and have the same source - human needs - whose satisfaction directs the actions specific to each area. Both security and the economy relate to the individual, to his needs and development. Insecurity and violent conflict are among the biggest obstacles in the way of achieving objectives in terms of development.

Relations between security and the economy, concern both regional and global organizations (EU, OSCE, NATO, UN), states' representative institutions (parliaments, governments), specialized institutions (SIPRI, The World Bank, The International Institute for Strategic Studies, Deloitte, PwC), nongovernmental organizations (Amnesty International, Transparency International, Institute for Economics and Peace - IEP), and many researchers (Collier, P., Ronis, S., O'Donnell.C., Stiglitz J., Stern M. \& Öjendal J, J. Justino P.). Assessments expressed support the idea of connecting the two areas and extending the security sphere (Barry Buzan, The Copenhagen School), so as to reflect the new risks and threats in the global environment, manifestation areas (military, political, economic, cultural, demographic, environmental, etc.) and the actors involved in managing them.

Economic development and security are objectives which guide the UN's actions, which are based on the belief that, together, the two areas are crucial for sustainable development. Incidentally, each of the 17 sustainable development goals contained by the UN Agenda 2030 can help in practice with the implementation by each state to eliminate most of the causes of conflicts and, therefore, reduce them and increase the level of security.

Security is an essential element of the EU's approach and the first step towards restoring peace and development at country level. Expressions of a unitary approach to security and development occur in several EU documents that support the intensification of efforts for development and poverty eradication in peace and security. Thus, in its Resolution on Security Policy, adopted by the European Parliament on 10 June 1991, it is considered that "Security is more than just preventing war, because it is also based on economic, environmental, demographic, technological aspects, as well as on those of social and international interaction" [3].

Also, EU's global approach to foreign conflicts and crises stresses the link between security and development, recognizing that "sustainable development and poverty eradication require peace and security", but also that the reverse postulate is equally true [4]. The connection between security and economics is also stressed in the declaration of the NATO Summit in Wales (4 - 5 September 2014), which states that security is the foundation of prosperity.

Nationally, the security concept has been expanded to include in its sphere other areas in addition to the military, namely: the economic, social, political, technological and environmental ones. Integrating these areas within the sphere of security is determined by the characteristics of the current security environment and reflects the possibility that in certain circumstances the issues faced by each of the areas to turn into security risks. Thus national security could be affected by the failure of Romania's development objectives, having as main causes: persistent economic difficulties, proliferation of shadow economy and corruption, increasing tax evasion, precarious infrastructure or 
perpetuating the development gap in the European Union and low resistance to major turbulence in foreign markets. [5].

As far as social risks are concerned we could consider as the main drivers of shortcomings the deficiencies in the education and health systems or labor market distortions. Regarding the latter highlighted factor we ought to show that often an economic environment that does not generates employment and where competition and investment are affected can turn into an outbreak of internal conflicts which, depending on the size gained can endanger the internal security of the state.

Another factor that could have an impact on all aspects of security is economic and financial crime. The diverse forms that it is found in, the dimensions acquired and the association, more often than not with the shadow economy and corruption, are just some of the reasons for all States to intensify their efforts of identifying effective ways to combat/reduce it. Actions directed towards this end are all the more necessary if one considers that the above mentioned phenomena affect every economy no matter how strong it is and the consequences are huge not only at the enterprise level, but also at the state level. Thus, as results from a survey conducted by PwC in 2014 show, the most common form of economic crime is theft, indicated as such in the survey by $69 \%$ of respondents. This is followed by fraud in procurement procedures (29\%), corruption $(27 \%)$, cybercrime $(24 \%)$ and accounting fraud (22\%). Other reported crimes include money laundering, mortgage and tax fraud [6].

The mentioned phenomena have devastating consequences from the level of organizations, across states and regions to global level. Major damage to the economies and respective state budgets are felt in full at security and defense levels. The losses in tax revenues collected roll under the domino effect on the level of resources allocated by the state for funding public institutions and therefore those allocated for investments in security. To get a clearer picture on the scale reached we mention the results of the study conducted by the Association of Certified Fraud Examiners, according to which the reported average losses of companies from acts of economic crime is $5 \%$ of revenue each year. By applying the percentage to the gross world product estimated for 2013, it results in a potential loss worldwide driven by fraud of nearly $\$ 3.7$ trillion [7].

In the analysis performed by the Institute for Economics and Peace (IEP) a "critical point" was identified between peace and corruption which suggests that beyond a certain point, a small increase in corruption can lead to large decreases in peace [8].

Often, the ramifications of corruption extend in all areas, affecting economic competitiveness, investment, social welfare, quality of public services and even administrative acts, the damage on states being an impressive one. The European Commission estimated that in 2014, the costs of corruption for the European economy at 120 billion per year, or nearly $1 \%$ of the GDP of the European economy but only the direct effects of corruption were taken into account. Globally, the cost of corruption equals more than $5 \%$ of GDP per capita. [9]. Instead, according to the analysis conducted by the RAND Europe Institute in 2016, where both direct and indirect effects of corruption were taken into account, the results of the moderate scenario suggest that at European level corruption costs amount to 990 billion US Dollars per year, while in Romania to 42.9 billion US Dollars per year or $15.60 \%$ of the GDP [10], the highest level in the EU.

These data alone and we still have enough to understand why corruption is contained in the Security Strategy of Romania in the category of factors that can render the state and its security level vulnerable. With the purpose of preventing, detecting and reducing economic and 
financial crime and corruption specialized state institutions acting at central or local level join efforts, such as: Court of Auditors, the National Anticorruption Directorate (DNA), Supreme Council of National Defense, National Agency for Fiscal Administration (ANAF) and the Directorate for investigating organized crime and terrorism offenses (DIICOT), but also institutions established by law within defense and security institutions, among which we enumerate: The Romanian Intelligence Service (SRI), the General Anticorruption Directorate (DGA) of the Ministry of the Interior (MAI); The Economic Crime Investigation Service of the Romanian Police, the General Directorate of Defense Intelligence (DGIA) and the Directorate for Preventing and Investigating Corruption and Fraud within the Ministry of National Defense (MApN).

\section{Economy as a Generator of Security Resources}

As demonstrated, an economy can become stronger (more competitive) and functional where there is peace and security, but the results depend largely on the access to resources, high technology and education. An essential role in this regard is played by state institutions which, through the legal framework created, but also through the implementation of normative acts, can influence greatly, both economic performance and security, as advocated also by Nobel-winning economist Douglass North [11].

Under the provisions of the laws underlying the establishment of security and defense institutions they cover activities that contribute to the provision of general public needs, namely the provision of a public good - security. Through the tasks entrusted their work does not aim at producing goods / services that may be subject to profit-generating transactions and, consequently, obtaining financial resources with which to finance themselves. Thus, based on the role assigned by society, the financial resources necessary to finance security sector beneficiaries are provided by security beneficiaries - public and private entities and citizens - by paying taxes set up as their obligations to the state.

The resources allocated to defense are part of the resources redeployed from the gross domestic product to public budgets, mainly through taxation. Going on this idea we might conclude that the higher the tax base (revenue, profit, turnover, wages etc.) the higher the level of resources collected by the state at its disposal and, therefore, the funding for defense could be more consistent. Reality shows, however, that the increasing trend in the level of economic resources generated is not always found in the volume of attracted resources or the budget allocated for defense.

Referring to Romania, according to data released by specialized institutions [12], there is both a low efficiency in taxation (VAT decreased from 0.64 as it was in 2008, when the economic crisis broke out to 0.52 in 2014) and in the collection of tax revenues (Table 1).

We have a suggestive image of the assertions if we look at the tax revenue collected by Romania compared to those collected by other EU member states. Some of the selected states are old EU Member States and have higher development levels than Romania (Austria, Great Britain, Germany, France, Sweden, Netherlands), and the others joined the EU in the last two waves, and have development levels close to that of Romania (Hungary, Slovenia, Czech Republic, Poland and Slovakia integrated in 2004, and Bulgaria integrated with Romania in 2007). 
Table 1: The share of tax revenues in GDP

\begin{tabular}{|l|c|c|c|c|c|c|c|c|}
\hline & $\mathbf{2 0 0 8}$ & $\mathbf{2 0 0 9}$ & $\mathbf{2 0 1 0}$ & $\mathbf{2 0 1 1}$ & $\mathbf{2 0 1 2}$ & $\mathbf{2 0 1 3}$ & $\mathbf{2 0 1 4}$ & $\mathbf{2 0 1 5}$ \\
\hline EU Average & 39.1 & 38.5 & 38.5 & 38.9 & 39.5 & 39.9 & 40.0 & $\mathbf{4 0 . 0}$ \\
\hline France & 46.4 & 44.1 & 44.2 & 45.5 & 47.3 & 47.7 & 48 & 47.8 \\
\hline Austria & 42.4 & 42.0 & 41.8 & 41.9 & 42.5 & 43.4 & 43.6 & 44.4 \\
\hline Sweden & 44.7 & 44.9 & 44.0 & 43.3 & 43.4 & 43.7 & 43.6 & 44 \\
\hline Germany & 39 & 39.4 & 38.1 & 38.6 & 39.1 & 39.3 & 39.3 & 39.6 \\
\hline Hungary & 39.5 & 39.1 & 37.4 & 36.8 & 38.4 & 38.1 & 38.5 & 39.2 \\
\hline Netherlands & & 35.9 & 36.7 & 36.4 & 36.9 & 37.7 & 37.7 & 37.6 \\
\hline Slovenia & 37.7 & 36.6 & 37.3 & 36.9 & 37.3 & 37.1 & 36.8 & 37.0 \\
\hline United Kingdom & 37.6 & 34.7 & 35.4 & 35.7 & 35 & 34.8 & 34.3 & 34.8 \\
\hline Czech Republic & 32.9 & 32.0 & 32.0 & 32,4 & 34.3 & 34.9 & 34,2 & 34.6 \\
\hline Poland & 46.9 & 32.3 & 32.2 & 32.7 & 33 & 32.7 & 33.0 & 33.4 \\
\hline Slovakia & 38.6 & 28.9 & 28.2 & 28.8 & 28.4 & 30.4 & 31.1 & 32.1 \\
\hline Bulgaria Processing on Taxation Trends in the European Union, European Union, 2015 & \\
\hline Romania and the Annual Report 2014 of the Fiscal Council of Romania, 2015 & \\
\hline
\end{tabular}

As is apparent from the data presented in the table, Romania returned to a level of collection of tax revenues of $28 \%$ of the GDP, but ranks last in the EU, with a difference of 12 points compared to the EU average of $40 \%$ of the GDP. The most powerful states in the EU also have the most efficient tax collection, voluntary tax compliance indicating awareness of the citizens of the respective states of the state's role in improving public policies and services whose beneficiaries they are.

Romania is currently trying to break the vicious circle of shadow economy and high corruption, the reduced level of tax revenues collection and of public budgets insufficient compared to the obligations of state. In this regard, we should stress the measures taken to strengthen state institutions and improve the legislative framework underpinning the collection and spending of public funds (Amending the Tax Code and the Law on Public Procurement), as well as increasing transparency in the use of resources allocated to public institutions, including those in the field of security and defense (the National System of Verification, Monitoring, Reporting and Control of Financial Statements, Legal Commitments and Budgets of Public Entities in Romania).

As apparent from the above, the volume of resources earmarked for security and defense is dependent on the economic performance of countries, the volume of resources collected from security beneficiaries having the status of taxpayers but also the priorities set by policy makers for financing in a financial year, quantified in the level of resources allocated to publicly funded institutions.

The reflection of the economic performance of the state on the security level of the respective State will be highlighted by the presentation in parallel of the evolution of the budget allocated to Ministry of National Defense of Romania, in nominal terms and as a percentage of the GDP. 


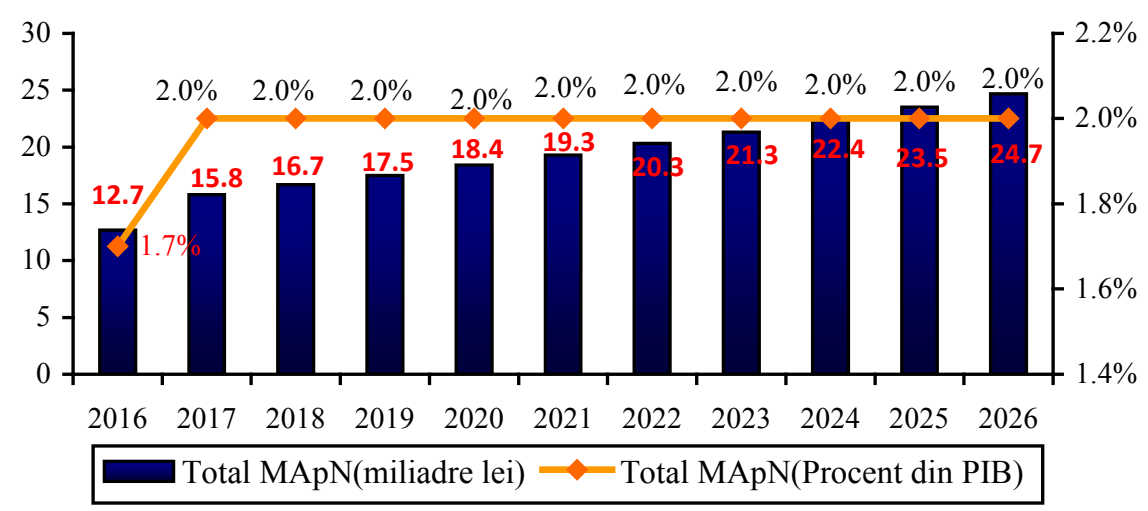

Figure 1: Estimated financial resources to be allocated during the period 2016-2026, Carta albă a apărării, 11.04.2016

The data presented highlights how while maintaining constant the percentile value of the GDP allocated for defense, the funding level increases with the increase of the GDP. Thus, in 2026 the level of funding would be, in relative terms, $94.4 \%$ higher than in 2016. Through the commitments made at the Summit held in Wales in 2014, but also through the National Political Agreement on increasing defense funding, Romania aims to halt the decline of defense funding, increase investment in security, support multi-annual budgetary planning of military spending, in order to ensure the predictability of the equipping policy of the Romanian Military and reduce inefficiency in defense budget spending and improve expenditure structure.

\section{Conclusions}

It is, behold, obvious that, in the new security environment, marked by profound and complex changes, as well as by financial constraints, sustained economic growth could entail funding that lead to increased levels of capabilities of the security and defense sector institutions. Investments in equipping and training, the formation of modern forces, robust and capable of a high level of preparedness will be able to face current and future challenges. All security efforts will have to be based on sustainable expenditure, security benefits generating wealth both for present generations and for future ones. The Romanian state will become a credible provider of security, contributing to the strengthening of regional and global security, able to cope with economic shocks, but also with security risks.

\section{References}

[1], [2] Dicţionarul explicativ al limbii române, Academia Română, Institutul de Lingvistică "Iorgu Iordan”, 2nd Ed., Bucharest, 1998, p. 969, p.329.

[3] Lista de definiţii şi termeni suplimentari din domeniul securităţii şi apărării, propusă de organizatorii reuniunii NATO "Politica de apărare şi strategia", Bruxelles, 22-23 Oct. 1996, p.1.

[4] Commission report to the European Parliament and Council, Annual Report 2014 on the European Union's Development and External Assistance Policies and Their Implementation in 2013, Bruxelles, 13.8.2014, p.5.

[5] Strategia naţională de apărare a ţării pentru perioada 2015 - 2019, O Românie puternică în Europa şi în lume, Bucharest, 2015, p. 15.

[6] Global Economic Crime Survey, PwC, 2014, p.4. 
[7] Association of Certified Fraud Examiners, Report to the Nations on Occupational Fraud and Abuse, 2014 Global Fraud Study, p.4.

[8] Global Peace Index 2014, Measuring Peace and Assessing Country Risk, Institute for Economics and Peace (IEP), 2014 / 01 / Results, Findings \& Methodology, p.53.

[9] European Commission, Report from the Commission to the Council and the European Parliament, EU Anti-Corruption Report, Brussels, 3.2.2014, COM (2014) 38 final, p.3.

[10]Study the Cost of Non-Europe in the area of Organized Crime and Corruption, Brussels, European Union, March 2016, p.43.

[11]North, D. Institutions, Institutional Change and Economic Performance, USA, Cambridge University Press, 1990, p.137.

[12]Fiscal Council, Annual Report 2014, Romania, November 16, 2015, p.42.

\section{Bibliography}

1. Taxation trends in the European Union, Data for the EU Member States, Iceland and Norway, European Union, 2015.

2. Carta albă a apărării din 11.04.2016, in effect from 22.04.2016. 